\title{
Effects of Commitment, Motivation, Climate and Authentic Leadership on The Performance of Madrasah Teachers
}

\author{
Dedi Achmad Kurniadi \\ Universitas Pendidikan Indonesia \\ Bandung \\ aan_komariah@upi.edu \\ Eka Prihatin \\ Universitas Pendidikan Indonesia \\ Bandung
}

\author{
Aan Komariah \\ Universitas Pendidikan Indonesia \\ Bandung \\ Asep Sudarsyah \\ Universitas Pendidikan Indonesia \\ Bandung
}

\begin{abstract}
The objective of this research is to verify that commitment and motivation as personal factors along authentic leadership and school climate as environmental factors affect teacher performance. Respondents of this research are teachers of Madrasah Aliyah in Tasikmalaya District. Correlational research method with Structural Equation Modeling with LISREL (Linerar Structural RELationship). Research findings show that commitment, Achievement of motivation, and school climate have direct effects on teacher performance, while authentic leadership has an indirect effect through school climate.
\end{abstract}

Keywords-Authentic leadership. Commitment and Motivation, School Climate, Performance of Madrasah

\section{INTRODUCTION}

Madrasah is a place for learning process of Islamic teachings formally. HAR Gibb and Kramers JH (Ahid, 2010:336)defined madrasah as "name of on institution where the Islamic science are studied".The equivalent of madrasahin bahasa Indonesiais school, so that in this research, madrasah is translated into school.

Quality of madrasah must be improved by the increasing demand on changes and problems, for example lack of student interest, delayed teachers and other educational personal to obtain information on progress, and problems on madrasah management that is considered to not show the sacred mission of religious education, namely to act sincerely. [1] Madrasah has some weaknesses, among others are that the madrasah management system is not fully managed with professional management, it tends to be traditional one. Also, madrasah principal as the madrasah manager is yet professional.
There are problems faced by madrasah aliyah teachers quantitatively. There is also problem related to their qualification, namely there is only 72 percent having education qualification of S1 or more, meanwhile, there is 28 percent still having education specification not S1. Also, there are professionality cases, such as mismatch and underqualified.[2]

Institutionally, madrasah has been acknowledged its existence formally by the government, so that the government provides similar position as public school. However, in its practice, there are still tremendous gaps mainly caused by difference on school and madrasah managements. Madrasah seems to be put in the second position by regional government neglecting on the existence of madrasah. This certainly causes lack of access for madrasah teachers to improvement of professionalism and welfare.

Madrasah institutional problems are worsened by lack of teacher quantity, qualification and competency, these lead to some questions concerning teacher performance on madrasah. By these limited quantity, qualification and competence, will madrasah teachers be able to present optimal performance? Meanwhile, there are some researches having conclusion that in achieving high performance level, it is necessary for high competence, commitment and motivation.[3]

Teachers face greatly crucial problems at madrasah, it is not only in terms of quantity and qualification, the one getting most concern is about improvement of professionalism facing many obstacles. Aslam, et.al (2010:11), showed that there are 11 main inhibiting factors on teacher performance, namely: 1) lack of exposure on teaching, 2) too much burden, 3) limited evaluation, 4) lack of trainings, 5) inadequate material and facilities, 6) lack of 
effective communication, 7) problems concerning student counseling, 8) disciplinary problems in the class, 9) difficulties in assessing student work, 10) lack of career expectation in teaching, and 11) violation on student behavior. [4]

Currently, there are many researches on teacher performance, commitment, motivation, leadership and school climate. The researcher is interested to understand on teacher performance, commitment, motivation, leadership and school climate, mainly on madrasah teachers. The interest to study on teacher performance, commitment, motivation, leadership having ability to affect on teacher performance is caused by madrasah unique style. Also, the researcher thinks that madrasah faces academic and cultural problems leading to tendency to strengthen as well as weaken madrasah teacher performance.

Davis and Nestrom (1993 : 24) stated that there are factors to be measures for performance, namely "Ability" and "Motivation"with formulation created as Human Performance = Ability + Motivation . This is similar to Robbins (2003 : 233) expression stating that Employees performance is a function of the interaction of ability and motivation". [5]

This limitation implies that teacher performance is a function of interaction of ability and motivation. This is shown through the equation: Performance $=F(A x M)$ if there is one inadequate factor among two factors leading to negative effects on the performance. As stated by Cardy and Leonard (2011: 2010), that performance is a function of ability and motivation, if there are low ability and motivation then there will also create low performance. While Komariah (2012) described that the teacher performance is a comprehensive performance based on ability, motivation and commitment in performing their professional duties as teachers. If these three elements are not applied comprehensively, although in different sizes, then there will be not optimalperformance. [6]

Performance having harmony with the performance based on Terence (1988:410) has measurements including five aspects namely: quality of work, promptness, initiative, capability, dan communication. The five aspects are related to the teacher teaching performance in terms of teaching planning, applying teaching and evaluation of learning outcomes. [7]

To achieve good teacher performance, it is necessary for performance criteria, as quoted by Gibson, et.al (Dunda, 2005:72) namely:(1) intellectual ability, (2) confirmation, (3) spirit (anthusiasm), (4) result-orientation, (5) fair adulthood attitude and behavior, (6) Assertive, (7) interpersonal skill, (8) curiosity, (9) Productive, (10) openness, (11) ability empowerment, (12) technical, knowledge, skill, decision, behavior and responsibility. [8]

Ivor K. Davies (1991: 35-37) stated that one has four general functions as the characterize of employee as a teacher, namely: (1) planningis that the work of a teacher is to prepare learning goals, (2) organize is that the work of a teacher is to organize and connect learning resources to realize learning goals in the most effective, efficient, and economical possible way; (3) leading is that the work of a teacher is to motivate, encourage, and stimulate students so that they are ready to realize learning goals, (4) monitoring is that the work of a teacher is to determine whether his function in organizing and leading above have been realized successfully the formulated goals.[9]

Based on some expert understanding on the performance, there is still lack of discussion onthe existence of commitment. Organizational commitment involves loyalty of employees on the organization, willingness to use business on behalf of the organization, level of conformity of goals and values with the organization, and willingness to maintain membership (Cohen, 2007). Teachercommitment to the organization is teacher adherence to madrasah, willingness to perform responsibilities as a teacher on behalf of the madrasah, level of conformity of goals and values with the madrasah, and willingness to remain as a madrasah teacher. [3]

Sweeney and McFarlin, (2002: 60), proposed three components of organizational commitment, namely affective commitment, rational commitment, and normative commitment. Affective commitment is related to emotional self-identification of teachers resulting in teacher willingness to have conscious self-involvement in madrasah institutions. Rational commitment or continuance commitment is related to profit and loss if the teacher leaves the madrasah institution, and normative commitment is related to teacher feeling of obligation to keep working in the madrasah institution. The three components of this commitment are possessed by teachers in different degrees and are influenced by different antecedents. [10]

From the performance researches, one important factor that is rarely examined related to teacher performance is commitment, whereas person-job fit is one of the factors affecting on teacher performance. According to the researcher, the lack of teacher commitment to their work will undermine teacher performance,not only lack of school motivation, leadership and climate. Therefore, other contributing factors affecting on the teacher performance in madrasah are motivation, leadership, and school climate.

In this research, it studies on motivation, namely intrinsic motivation as a motivation mainly resulted in selfencouragement. The relevant motivation theory as the reference is motivation theory by Alderfer namely ERG Theory(Existence, Relatedness, Growth), expressing three human basic needs namely Existence needs, Relatedness needs, and Growth needs. [11]

Not only intrinsic motivation factor, the researcher also thinks that the performance of madrasah teacher is also affected by any outside factors, namely principal leadership and school climate. In this research,it is studied principal 
leadership factor based on the authentic leadership theory by George (2003),namely type of leadership prioritizing on self-awareness on other dimensions. In its practice, it should consider 5 dimensions of authentic leader, namely purpose, values, heart, relationships, dan self-discipline.[12]

There is also another aspect affecting on the teacher performance namely the school climate, Rahmat (2012 :) drawn conclusion from his research that the absence of a conducive school climate can degrade quality of learning services. [13]. The school climate has a healthful impact on the institutions through spirit and commitment of teachers to create qualified learning process having orientation towards the mastery or development of academic excellence and cultivation of intellect (Supriatna, 2011: 22). The school climate used in this study is based on the organizational climate by Hoy and Miskel (2008: 221), that the organizational climate refers to the perception on general school environment affected by formal organization, informal organization, member personalities, and leadership in organizations. The indicators are cooperation, openness, tolerance, and intimacy. [14]

Based on the above description, it can be concluded that there are two major factors affecting on the teacher performance, namely personal factor and environmental factor. Personal factor consists of intrinsic commitment and motivation, while environmental factor consists of principal leadership and school climate. The researcher thinks that both factors simultaneously provide significant effects on the performance of madrasah teachers.

In addition, the researcher estimates that personal factor provides greater impacts on the performance of madrasah teachers than the environmental factors because the personal factor is more sedentary and more difficult to change than the environmental factor. While there are two environmental factors, namely climate and leadership factors. The researcher thinks that leadership has direct effects on the performance of madrasah teachers, while the authentic leadership provides indirect effects on the madrasah climate. This opinion is based on the idea that the principal leadership can create conducive school climate giving encourage to the teachers to improve their performance.

From the description above, there are main issues in this study namely: (1) whether there is any conformity of theoretical model illustrating the direct effects of commitment, motivation, and leadership, as well as the indirect effects of madrasah climate to explain the performance of madrasah teachers in Madrasah Aliyah in Tasikmalaya Regency. And (2) whether the commitment and motivation have greater direct effects on the performance of madrasah teachers in Madrasah Aliyah in Tasikmalaya Regency compared to madrasah leadership and climate.

\section{RESEARCH METHOD}

This field study uses quantitative method, with questionnaire as the data collection tool. The research respondents are madrasah teachers as active civil servants working permanently for minimally 2 years in state and private Islamic senior high school. The data is taken from 140 respondents as the selected samples including 40 teachers of State Aliyah and 100 teachers of private Aliyah. The questionnaire consists of five sections, namely research measure consisting of Organizational Commitment scale from Sweeney and McFarlin (2002) [10], ERG Motivation Survey scale from Clayton Alderfer (1988) [15], The Organizational Climate Description Questionnaire (OQDQ) developed by Hoy and Miskel (2001) to measure school organizational climate, [16] AL (authentic leadership) survey scale from George (2003) [12] and measurement tool of performance from Sedarmayanti. [17]

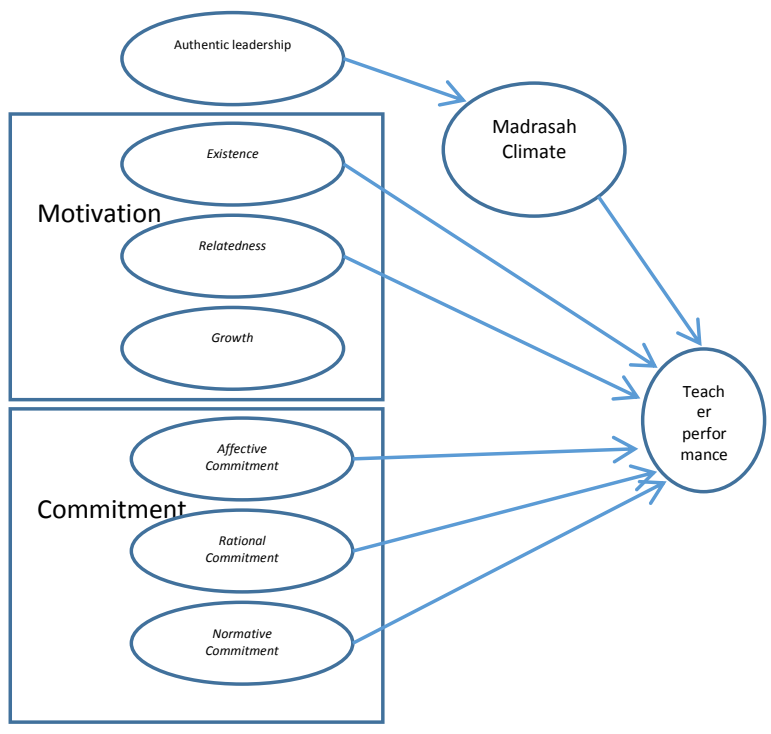

Figure 1. Research Model

There is modification on measurement scale so that it is well-adjusted to work characteristics and context of madrasah teachers. All scales used in this study have scores ranging from 1 (very low) to 6 (very high). The entire measurement scales are tested on Aliyah teachers having the same characteristics as the research respondents. The tests are conducted to find out the reliability and validity of each measurement instrument by applying Cronbach Alpha's statistical analysis technique for the reliability and Pearson Product Moment to test the validity of statements.

To examine the effects of commitment, motivation, school climate, and leadership on the performance of madrasah Aliyah teachers, it is used the structural equation model analysis technique by applying LISREL (Linear Structural Relationship) software. Through the LISREL program, itis conducted: (1) analysis of measurement model on the factors, it aims to obtain measurable variables as 
good indicators for each latent variables of research, and (2) structural model analysis, namely the compatibility between theoretical model and the data as well as significance of each causal relationship coefficient (Pedhazur \& Schmelkin, 1991). If the results of analysis show that the theoretical model proposed by the researcher is not in accordance with the research data, then it can be proposed another model considered as the more appropriate one. [18]

\section{RESULTS AND DISCUSSION}

Analysis of Measurement Model

The analysis of measurement model is the factor analysis using confirmatory method conducted to obtain measurable variables as the indicator of a latent variable. In the first stage, it is conducted the factor analysis using confirmatory and it is found out that all of the forming factors of each research variable are valid in forming the latent variables.

There are four components out of five component of Aliyah teacher performance, namely quality of work, promptness, initiative, capability, and communicationas good indicator for teacher performance, except for promptness. There are three components of Organizational Commitment by Sweeney and McFarlin, namely affective commitment, rational commitment and normative commitment as the good indicator for the organizational commitment. Also, there are three components of ERG Motivation as the good indicators for the teacher motivation.The Organizational Climate Description Questionnaire (OQDQ) components namely Hindrance, Intimacy, Disengagement, and Espritare good components for organizational climate of teacher factor, meanwhile, the Production emphasize, Aloofness and Trust are not fit to measure school climate of teacher factor. There are five components of the authentic leadership namely purpose, values, heart, relationships, and self-discipline as the good indicators for the authentic leadership.

Based on the results, it is conducted trimming (model reformulation) by eliminating promptness factor in teacher performance, Production emphasize, Aloofness and Trust factors in school organizational climate. Based on the results of second analysis after model reformulation, it is obtained structural model (standardized solution) as presented in Figure 2.

The structural equation model analysis is conducted by engaging the indicators selected based on the factor analysis results. Based on analysis results on the model proposed by the researcher, it is obtained the $\chi^{2}$ value not meeting the criteria so that the researcher proposed the second model. The analysis results on the second model show that the model is fit to the research data $\left(\chi^{2}=93,66 ; d f=62, \mathrm{p}=\right.$ $0,007 ; G F I=0,92 ; R M S E A=0,028)$. The effect path, amount of effects and factor loading of the indicator of each latent variable in the second model can be seen in Figure 2 as follow.

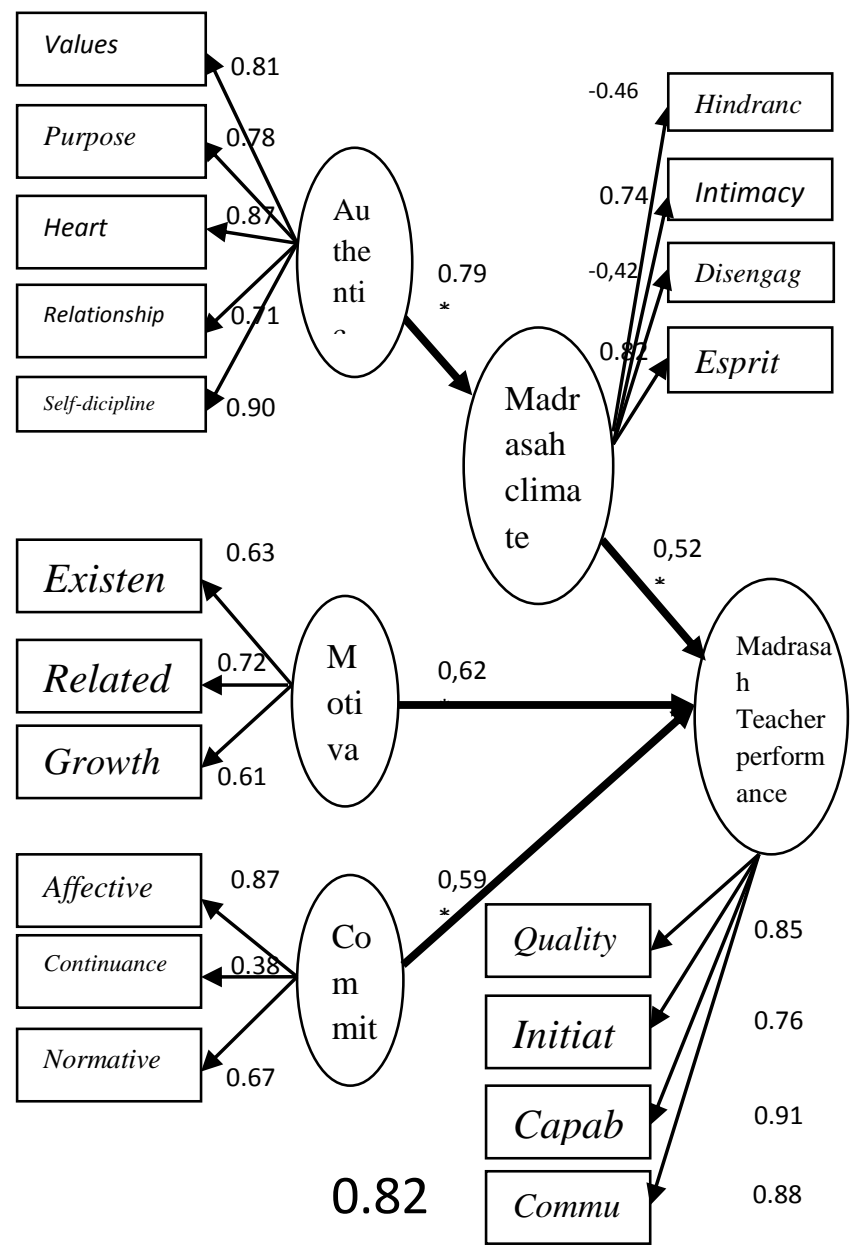

Figure 2. Results of Structural Equation Model Analysis

From the results of structural model analysis, it is found out the research answers as follow:

1) The theoretical model consisting of motivation, commitment, and madrasah climate are fit to explain the performance of madrasah teachers.

2) Motivation has direct positive and significant effects on the performance of madrasah teachers.

3) The performance of madrasah teachers positively and significantly is influenced by the commitment of lecturers, namely teacheremotional attachment to the madrasah, feeling to have loss when leaving the madrasah, and the sense of obligation by the teacher to keep working at the madrasah.

4) There is a positive and significant direct effect of the madrasah climate on the teacher performance.

5) The madrasah climate is a mediator variable between the authentic leadership and the performance of madrasah teachers.

Based on the research findings, it can be concluded that: (1) higher existence of the madrasah teachers leads to 
stronger attachment to madrasah, and more rapid career of madrasah teachers, higher performance of madrasah teachers. (2) higher teacher emotional attachment to the madrasah leads to higher feeling of loss when leaving the madrasah, and higher sense of obligation by the teacher to keep working at the madrasah, higher performance of madrasah teachers. (3) higher role of the principal in making the values as the basis of foundation leads to more clear objective formulation by the madrasah, more involvement of clear heart in the leadership, stronger ukhuwah or relationship, higher hard work of principal, more conducive madrasah climate; And (4) more conducive madrasah climate leads to higher performance of madrasah teachers.

\section{DISCUSSION}

This research is conducted at Madrasah Aliyah in Tasikmalaya Regency as a regency with popular call as a Santri city. To obtain the respondents, it is facilitated by officials at Religious OfficeTasikmalaya regency, supervisor and principal who are studying S3 at UPI post-graduate program where the researcher is on duty. These respondents already represent the madrasah aliyah teachers in Tasikmalaya regency and have reached the minimum limit to perform the structural equation analysis, namely ranging from 100-150 people (Ding, Velicer, \& Harlow (Schumacker \& Lomax, 1996). [19]

The significant effects of school motivation, commitment, and climate on the performance of aliyah teachers indicate that the personal factors and environmental factors simultaneously affect on the performance of aliyah teachers in Tasikmalaya regency. Meaning, although the personal factor serves an important role in building the teacher performance, the environmental factor also playsdetermining role.

Thus, the madrasah in this case the madrasah principal should consider both factors in maintaining and improving the performance of madrasah aliyah teachers. The results of this research are in line with a research conducted by Sezgin, (2009: 630), [20] stating that there is a significant relationship between teacher commitment and the organization on its performance. And in line with the results of research by Geijsel, etc (2003: 228), having results stating that the transformational leadership has positive and significant effects on the teacher commitment and performance. These findings indicate that the commitment as an internal factor of teachers and the leadership as an external factor have significant effects on the manifestation of teacher performance. Although most research results are taken from schools but the factors affecting on the teacher performance at schools are similar to the factors affecting on the teacher performance in madrasah.[21]

Thus, it can be concluded that although madrasah has different characteristics to schools, as well as performance of madrasah teachers reflects different working dynamics to teachers at schools, the theories and research results applied and found at schools can also be applied to madrasah.

The high effects of motivation on the teacher performance show that the teacher performance is determined by level of teachermotivation, namely high or low. It also means that madrasah teachers with high motivation in performing their work are madrasah teachers who are always in madarasah, having emotionally attached feeling to madrasah, and having progressive career growth in madrasah. This is in line with a research conducted by Wardana (2008: 27) having conclusion that the motivation has positive and significant effects on the performance of elementary school teachers [22] and a research by Indrawati (2006) stating that knowledge / ability, skills and motivation factors affect on the performance of teachers. This finding is very rational because of attached motivation by the teachers, mainly the intrinsic motivation. [23] Dimyati and Mujiono (2009: 50) described that any individual (internal motivation) factors can lead to encourage cooperation for the improvement of teacher performance. [24]

There is also finding showing that teacher commitment to madrasah has high effect on the performance; That the performance of madrasah teachers is determined by level of teacher commitment to their work as teachers in a religious institution. It also means that madrasah teachers with high commitment to the madrasah are teachers with emotional attachment to madrasah, obligation feeling to keep serving and keep working in the madrasah as a part of devotion to Allah SWT.

This result is in line with the main reason causing the respondents choose a job as a madrasah teacher because there is a call to be 'rahmatan lil alamin' through the effort to spread knowledge as a part of ' $d a$ 'wah fil ardhi', although it seems that there is inadequate salary earned by madrasah teachers especially in private madrasah.

Self-discipline, heart and value are the most powerful indicators for the authentic leadership. In addition, selfdiscipline also provides significant relationship with quality of work, initiative, capability, and communication. This means that there is tremendous effect in forming, maintaining, and improving performance of madrasah teachers. The authentic leadership behavior by the principal is presented in the form of hard work and role model, not no action talk only. The results of this research are consistent with opinions by May, Chan, Hodges, \& Avolio, (2004) [25] stating that authentic leaders are leaders who must be honest to themselves, meaning to have conformity between behavior and belief.

Avolio et al. (2005) defined authentic leaders as leaders with good awareness on how they think and behave and are considered by other people as and by perspective of other people values, having moral strength, context and selfconfidence, full of expectation, optimism, strength and high moral character.[26] Principals of madrasah Aliyah are expected to have the ability to play their roles in creating 
conducive climate and ultimately to improve the teacher performance. Having this type of principals, teachers can obtain peaceful feeling and be role of model giving inspiration on the implementation of their duties appropriately. Related to be role of model and leader, Hill and Jones (2009), stating that there are five main keys causing followers to be really led, namely (1) Vision, eloquence and consistency; (2) Articulation of a business model; (3) Commitment; (4) Being well informed; (5) Willingness to delegate and empower; (6) Astute use of power; and Emotional intelligence.[27]

There are positive and significant direct effects of madrasah climate on the performance of madrasah teachers, this indicates that more conducive madrasah climate leads to higher teacher motivation to realize their performance professionally. Teachers can enjoy this type of madrasah climate particularly when they performing their performance, the madrasah as an institution does not prevent them in self-development especially to continue their studies, there is no friction or conflict among fellow teachers,but each teacher helps each other in the organizational intimacy, not being in conflicts, or living in their own affairs without knowing and having empathy to fellow problems. However, madrasah develops togetherness in facing any problems so that madrasah is a fun place to socialize and becomes a 'second home' for teachers and school staffs.

This finding is in line with the results of a study by Hoy and Miskel (2008: 201) stating that: “... openness in climate is positively related to open and authentic teacher and principal behavior."Open school climate has positive relationship to open and authentic teacher and principalbehavior. Closed and unhealthy school climate is believed to cause weak morale resulting in the decreased teacher performance.[16]

It is necessary for principal to maintain comfortable and enjoyable climates for teachers so that they can work to perform their work professionally. This can be applied by managing psychological climate, namely to create empathetic communication and mutual respect, as well as provideany necessary facilities and infrastructure for the teachers so that they can perform their work professionally, infrastructure for learning, and infrastructure to develop their careers. It is necessary to complete learning facilities in fact of lack of madrasah infrastructure and facilities in terms of library, practicum, internet access, learning tools and media. While the means for career development is in term of providing adequate space and place for knowledge sharing among teachers by forming empowered $\mathrm{KKG}$, MGMP to the programs to be realized.

\section{V.CONCLUSION}

This research finds out that all indicators affect on the formation of each latent variables of teacher performance, authentic leadership, madrasah climate, teacher motivation and commitment. There are positive and significant direct effects of madrasah motivation, commitment, and climate on the teacher performance. There are indirect and significant effects of the authentic leadership on the teacher performance. There is higher teacher internal factor effect, namely motivation and commitment than the external factor effects namely leadership and madrasah climate in forming the professional performance of teachers. Based on the findings of this research and for the improvement of teacher performance, it is recommended that madrasah principals focus on the institutional arrangements so that they can create conducive madrasah climate giving benefits for teacher performance and having ability to encourage teachers to have high motivation and commitment for their work and for their madrasah.

\section{REFERENCES}

[1] Badrussholeh. Problematikan Mutu madrasah dan Upaya Pemberdayaannya. http://badrussholeh_ guruindonesia.net/artikel_html. 2011

[2] Nur A. Problem Pengelolaan Madrasah Aliyah dan Solusinya. Islamica. 4(2):336-245

[3] Cohen, A. 2007. Commitment Before and After: A Reconceptualization of Organizational Commitment. Human Resource Management Review, 17 (3): 336-354.

[4] Aslam, Hassan Danial., Sarwar, Shakeel., Rasheed, Muhammad_Imran. Hindering factors of beginning teachers' high performance in higher education Pakistan: (Case Study of IUB-The Islamia University of Bahawalpur). International Journal of Education, 2010 vol 26: page 11 .

[5] Davis, Keith \& John W Nestrom. 1995. Perilaku Dalam Organisasi. Edisi Ketujuh, Terjemahan. Jakarta: Erlangga

[6] Komariah, Aan (2006). Visionary Leadership Menuju Sekolah Efektif. Jakarta: Bumi Aksara

[7] Terence, Mitchell R. 1988. People in organizations: An introduction to organizational behaviour in Australia. Sydney and New York: McGraw-Hill.

[8] Dunda, Juli Wahyu Pari. 2005. Konsep Kinerja Guru. Jurnal Pendidikan Asosiasi Kepala Sekolah Indonesia. vol 1 hal 70-79

[9] Ivor, K Davies. 1991. Pengelolaan Belajar. Terjemahan. Jakarta: Rajawali.

[10] Sweeney, PD., McFarlin, DB. (2002). Organizational Behavior:Solution for Management. New York: McGraw-Hill International Edition.

[11] Morgan, R. \& Baker, F. (2012). Developing a Conceptual Framework for Motivation of Professional Educators According to Content and Process Theories. In P. Resta (Ed.), Proceedings of Society for Information Technology \& Teacher Education International Conference 2012 (pp. 1216-1221). Chesapeake, VA: AACE.

[12] George, Bill. (2003) .Authentic Leadership; Rediscovering the Secrets to Creating Lasting Value.San Fransisco: Jossey-Bass

[13] Rahmat, Endang. 2012. Mutu Layanan Akademik Sekolah Menengah Atas.Disertasi tidak diterbitkan. Bandung: Sekolah Pascasarjana UPI

[14] Supriatna, Nana. 2011. Konstruksi Pembelajaran Sejarah yang Berorentasi pada Masalah Kontemporer Pembangunan. Mimbar, Vol. XXVII, No. 1 (Juni 2011): 21-30

[15] Alderfer, C. P. 1982. Existence, Relatedness, and Growth; Human Needs in Organizational Settings. New York: Free Press 
[16] Hoy, Wayne K and Miskel, Cecil G (2001). Educational Administration: Theory, Research and Practice. New York: McGraw-Hill

[17] Sedarmayanti. 2010. Manajemen Sumber Daya Manusia. Bandung : PT. Refika Aditama

[18] Pedhazur, E.J. dan L.P. Schmelkin. 1991. Measurement, Design, and Analysis: An Integrated Approach (Student Edition). Hillsdale, NJ: Lawrence Erlbaum Associates.

[19] Schumacker, R.E. dan R.G. Lomax. 1996. A Beginner's Guide to Structural Equation Modeling. Mahwah, NJ:Lawrence Erlbaum Associates.

[20] Sezgin, Ferudun. 2009. Relationships between Teacher Organizational Commitment, Psychological Hardiness and Some Demographic Variables in Turkish Primary Schools. Journal of Educational Administration. Vol. 47 Iss: 5, pp.630 - 651

[21] Geijsel, Femke., etc. 2003. Transformational Leadership Effects on Teachers' Commitment and Effort Toward School Reform. Journal of Educational Administration. Vol. 41 Iss: 3, pp.228 256

[22] Wardana, Ludi Wisnu. 2008. Analisis Pengaruh Motivasi Kerja, Disiplin Kerja, Pendidikan dan Pelatihan, terhadap Kinerja Guru Sekolah Dasar Negeri. Jurnal Ekonomi Manajemen dan Bisnis (EMAS). Vol II, no.1 April: Hal 27

[23] Indrawati, Yuliani. 2006. Faktor-Faktor yang Mempengaruhi Kinerja Guru Matematika Dalam Pelaksanaan Kurikulum Berbasis Kompetensi ( KBK ) Pada Sekolah Menengah Atas Kota Palembang. Jurnal Manajemen \& Bisnis Sriwijaya Vol. 4, No 7

[24] Dimyati, Mujiono. 2009. Belajar dan Pembelajaran. Jakarta: Rineka cipta

[25] May, D., Avolio, B., Gardner, W., Walumbwa, F. 2004. Unlocking the mask: A look at the process by which authentic leaders impact follower attitudes and behaviors. Leadership Quarterly, 15(6), 801-823.

[26] Avolio, B., \& Gardner, W. (2005). Authentic leadership development: Getting to the root of positive forms of leadership. Leadership Quarterly, 16(3), 315-338.

[27] Hill Jones. 2009. Journal of Strategic Leadership, Vol. 4 Iss. 1, 2012, pp. 01-08 